Valentina Golubović-Bugarski

Assistant Professor University of Banjaluka Faculty of Mechanical Engineering Republika Srpska Bosnia-Herzegovina

\section{One Approach to Correlation Between Structural Damage and Dynamic Response of The Cantilever}

This paper presents one approach in damage detection using frequency response functions data. The method based on damage detection and relative quantification indicator is used, in order to detect, locate and quantify the damage of the cantilever. Experimental modal investigation was conducted on the cantilever beam using hammer excitation and "roving hammer" method of modal testing. Proposed damage detection method shows good performance even for the hammer excitation and one response transducer available, which is important considering the practical implementation of the method in the frugally equipped laboratories.

Keywords: damage detection, modal testing, experimental FRF, modal frequencies, cumulative generalized damage index.

\section{INTRODUCTION}

Generally, damage can be defined as a change occurred in a system and negatively affects the current or future behavior of the system. If we restrict ourselves to the study of damage identification in mechanical structures and systems, the definition of damage can be limited to changes in the properties of the material and/or geometric properties of the system, including changes in boundary conditions and system connectivity, which adversely affect the current or future performance of the system. The problem of detecting structural damage in mechanical, aeronautical and civil engineering structures is analyzed and presented in a number of research papers in the last two decades. Traditional nondestructive test techniques, such as acustic and ultrasound method, radiography, magnetic field method, etc., may be useful for the identification of local damage. However, these methods usually require a test structure to be exempt from the work process, in order to carry out inspections at planned intervals. Such tests can be very expensive and time consuming, especially if they imply testing of components that are hardly accessible. These deficiencies were the main motivators for exploring new non-destructive testing technique which can be applied to various structures in their working conditions, and thereby reduce maintenance costs, improve safety and efficiency of the system. Among the most popular approaches to the damage detection is certainly the use of vibration data as the basis for monitoring the safety of structures. The term "structural health monitoring" means monitoring the safety of operation of mechanical structures and is relevant for implementation of damage detection strategy. This process involves defining the potential damage scenarios of mechanical systems, observation of

Received: $\mathrm{xxx} \quad$ Accepted: $\mathrm{xxx}$

Correspondence to: Valentina Golubović-Bugarski

University of Banja Luka, Faculty of Mechanical

Engineering, S. Stepanovića 71, 78000 Banja Luka, BiH

E-mail: valentina.gb@unibl.rs

doi:10.5937/fmet1404335G

(C) Faculty of Mechanical Engineering, Belgrade. All rights reserved systems over a period of time and performing periodic measurements, identifying and extracting relevant data derived from the measurement, and analysis of these data to determine the current state of the system performance. As an output from this process, periodically updated information is obtained, relating to the system ability to continuously perform its desired function, due to the fact that aging and degradation are inevitable as a result of the working conditions of a given system.

Since a structure damage causes the change of mass, stiffness and/or damping of the structure, vibration response of the structure due to the permanence workload or intentionally introduced excitation will also show some changes. Vibrationbased damage detection can be mathematically defined as a non-linear inverse problem, where measured vibration response is known, and parameters that determine the location and size of the damage which caused the change in vibration response pattern are to be determined. According to [1], there are four different levels in the diagnostics of damage:

- Level 1: identification of damage existence in a structure.

- Level 2: location of damage.

- Level 3: quantification the damage severity.

- Level 4: prediction of remaining service life of structure.

\section{A LITERATURE REVIEW OF THE DAMAGE DETECTION METHODS}

An overview of the various damage detection techniques using modal parameters of the system was given in papers [2-4]. The first comprehensive review of the technical literature concerning the detection, location, and characterization of structural damage via techniques that examine changes in measured structural vibration response was presented by Doebling and Farrar [2,3]. That report first categorizes the methods according to required measured data and analysis technique. The analysis categories include changes in 
modal frequencies, changes in measured mode shapes (and their derivatives), and changes in measured flexibility coefficients. Methods that use property (stiffness, mass, damping) matrix updating, detection of nonlinear response, and damage detection via neural networks are also summarized. The applications of the various methods to different types of engineering problems are categorized by type of structure and are summarized. The types of structures include beams, trusses, plates, shells, bridges, offshore platforms, other large civil structures, aerospace structures, and composite structures. Sohn [4] presents detailed report which is an updated version of the previous literature review report by Doebling. The authors have organized reviewed articles following the statistical pattern recognition paradigm reported in [2]. This paradigm can be described as a four-part process: (1) Operational Evaluation, (2) Data Acquisition, Fusion, and Cleansing, (3) Feature Extraction and Information Condensation, and (4) Statistical Model Development for Feature Discrimination. The reviewed articles are then categorized by type of applications, which include beams, truss, plates, bridges, aerospace structures, and composite structures. Yan [5] presents general summary and review of state-of-the-art and development of vibration-based structural damage detection methods based on structural dynamics characteristic parameters. They divide vibration-based structural damage detection methods into traditional type and modern type. The traditional type refers to detection methods for structural damage only utilizing eigen mechanical characteristic of structures, such as natural frequencies, modal damping, modal strain energy or modal shapes, etc. This kind of method generally requires experimental modal analysis or transfer function measurement, and the authors find it not convenient for online detection of structures in service, because these experimental measures often need multifarious instrument or manual operation. The modern type refers to detection methods for structural damage based on online measured response signal of structures in service. Among the modern type methods for structural damage detection, the representative ones include Wavelet analysis, Genetic algorithm and Artificial Neural Network, etc.

\section{THEORETICAL BECKGROUND OF THE DAMAGE DETECTION}

The equation of motion of a multiple-degree of freedom system with hysteretical damping, which is often used in describing of complex structure's dynamics [5], is:

$$
[M]\{\ddot{x}(t)\}+i[D]\{x(t)\}+[K]\{x(t)\}=\{f(t)\}
$$

If the excitation is harmonic, the realtion between the response and the excitation at each frequency of the analysis is given by:

$$
\{X\}=[\alpha(\omega)]\{F\}
$$

where

$$
[\alpha(\omega)]=\left([K+i D]-\omega^{2}[M]\right)^{-1}
$$

is the system receptance matrix, containing all the information about the dynamic characteristic of the system. Each element $\alpha_{j k}(\omega)$ of the matrix corresponds to an individual FRF describing the relation between the response at a particular coordinate $j$ and a single force excitation applied at coordinate $k$ :

$$
\alpha_{j k}(\omega)=\frac{X_{j}}{F_{k}}, \quad F_{i}=0, i=1 \ldots N ; i \neq k
$$

The column vector, $k$, of the receptance matrix, $\left\{\alpha_{k}(\omega)\right\}$, describes the shape (in space) exhibited by the structure at each excitation frequency $\omega$, given by the responses normalized by the applied forces.

When a structure is damaged its stiffness and damping change and, in consequence, so does the receptance matrix:

$$
\left[{ }^{d} \alpha(\omega)\right]=\left(\left[{ }^{d} K+i^{d} D\right]-\omega^{2}[M]\right)^{-1}
$$

where the superscript $d$ stands for damaged.

It is reasonable to assume that the smaller the degree of correlation between the column vectors, $\left\{\alpha_{k}(\omega)\right\}$ and $\left\{{ }^{d} \alpha_{k}(\omega)\right\}$, the larger the damage.

\section{FEATURES USED IN VIBRATION BASED DAMAGE DETECTION}

In order to detect structural damage from structural dynamic response, the first problem is to select damage feature index to be constructed. The physical variable used to identify damage may be a global one, but the physical variable used to determine damage location is better to be local one and must be sensitive to structural local damage. Determination of structural damage location is equivalent to determining a region where structural stiffness and loading capacity decreases using a measurable quantity. The key factor of vibration based damage detection is to establish the calculation model and to estimate the vibration parameter to be measured.

Common features used in vibration based damage detection studies are: 1) modal frequencies, 2) frequency response functions - FRF, 3) mode shapes, 4) mode shape curvatures, 5) modal strain energy, 6) dynamic flexibility, etc.

The techniques used to identify the damage from the measured data can be classified as: 1) methods based on frequency changes 2) methods based on mode shape changes 4) methods based on mode shape curvature changes 3) methods based on dynamically measured flexibility: comparison of flexibility changes, stiffness error matrix method, effects of residual flexibility, changes in measured stiffness matrix, 4) matrix update methods, 5) neural-network based methods, 6) timehistory and spectral pattern methods, 7) nonlinear methods, 8) statistical pattern recognition methods, etc.

He [6] classifies detection methods depending if experimental modal data, analytical modal data or FRF data is used for structural damage identification. Damage detection using only experimental data is 
approach if analitical, spatial model of the undamaged structure is not aveliable. Usually, the data available are the experimental data before and after damage occurred. As a result, we are dealing with two sets of modal or FRF data. The comparison of these two sets should yield the information about the existence and location of damage. The main question is how to relate the differences between modal and FRF data before and after damage to the spatial stiffness changes that resulted in the differences. Damage detection using modal data and analytical data is an approach that was largely adopted from model updating. Its algorithm aims to determine damage by using the modal data from a damage structure and an analytical model for its counterpart. Damage detection using measured FRFs for damage detection has many advantages over the traditional methods using modal analysis data: 1) any numerical errors inherent in modal analysis results caused by inaccurate curve fitting and unavailable residual terms are avoided; 2) no more efforts is needed to process FRF data in order to derive modal data; 3 ) the most significant advantages of using measured FRF data over derived modal analysis data lies in the fact that FRF data provide abundant information on the dynamic behavior of a structure. Modal analysis data lose much of the information that FRF data have, due to the necessary numerical process to extract them.

\section{AN EXPERIMENTAL DAMAGE DETECTION OF THE CANTILEVER BEAM}

When damage occurs in the structure, changes in the measured frequencies and mode shapes will result. Based on change in measured frequencies of the structure from its undamaged and damaged state, it is possible to identify that damage exist in the structure. To identify the location of damage it is necessary to establish some damage location model.

One example of the damage identification procedure according to the level 1, level 2 and level 3 (mentioned in Introduction section) is presented in this section, [7]. Experimental investigation was conducted for cantilever beam.

The steel beam of dimensions $400 \times 10 \times 10 \mathrm{~mm}$ was clamped at one end, forming the cantilever of $300 \mathrm{~mm}$ length, figure 1. Modal testing was performed by means of hammer excitation, using so called "roving hammer" testing methods. An impact hammer generated excitation on the each of 14 DOFs uniformly arranged along the beam. An accelerometer was attached to DOF 11 to capture the vibration response signals.

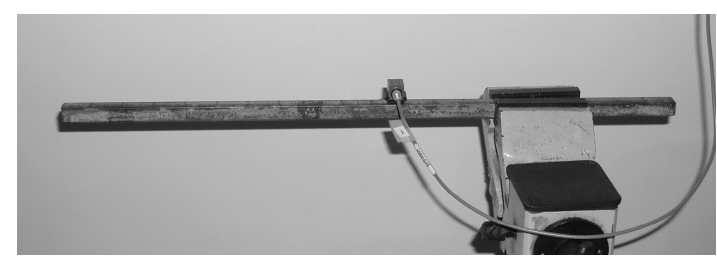

Figure 1. Cantilever steel beam

The damage was simulated as reduction of crosssection of the beam induced by the wire cut of $0.5 \mathrm{~mm}$ width, figure 2 .

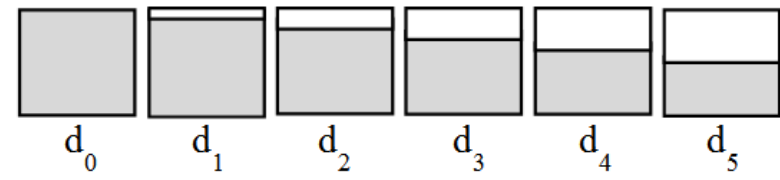

Figure 2. Damage simulated by reduction of cross-section

As one can see from table 1, the cantilever beam's FRFs were measured in 7 conditions: undamaged (or reference), one undamaged but different from reference state, and 5 levels of damage at certain location.

Table 1. Five different levels of the damage

\begin{tabular}{|c|c|c|c|c|c|c|}
\hline $\begin{array}{c}\text { damage } \\
\text { stage }\end{array}$ & $\mathrm{d}_{0}$ & $\mathrm{~d}_{1}$ & $\mathrm{~d}_{2}$ & $\mathrm{~d}_{3}$ & $\mathrm{~d}_{4}$ & $\mathrm{~d}_{5}$ \\
\hline $\begin{array}{c}\text { cut depth } \\
\text { [mm] }\end{array}$ & 0 & 1 & 2 & 3 & 4 & 5 \\
\hline
\end{tabular}

Three tests were done [7], for different location of the damage on the three beams, figure 4:

- test 1: damage is close to the place of clamping

- test 2: damage is in vicinity of the 3 th mode node

- test3: damage is far away from the place of clamping.
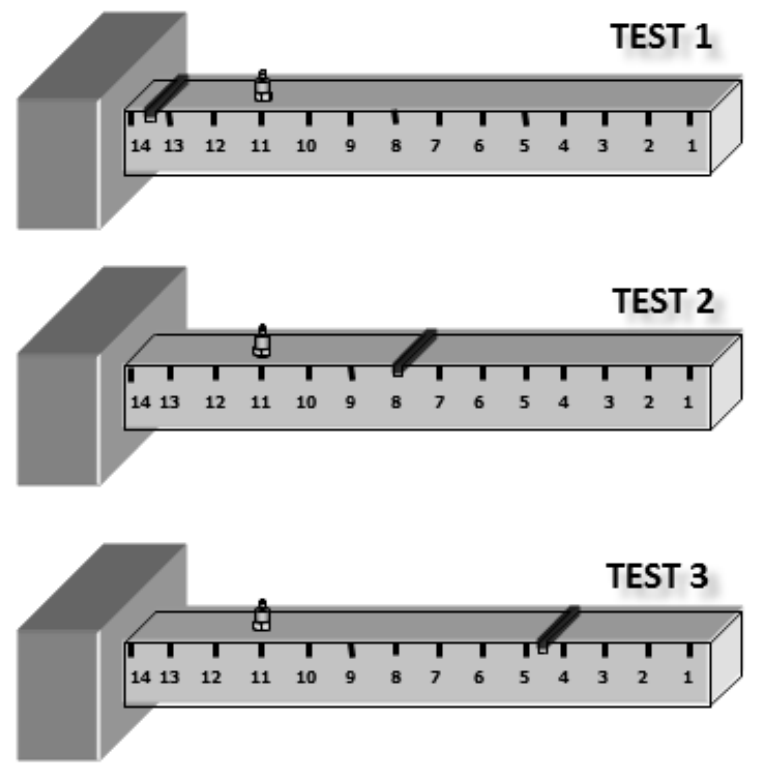

Figure 4. Three different damage location

Measurement data were collected using the multichannel data acquisition unit Portable Pulse type $3560 \mathrm{C}$ by Bruel\&Kjaer, and analyzed in the Pulse LabShop 9.0 software, in the frequency range of $0 \div 3200 \mathrm{~Hz}$. An impact hammer Endevco, type 2302-10, generates excitation, while the response was captured by modal accelerometer, B\&K type 4507, attached to the structure. Both signals were weighted by some window functions: the excitation signal by transient window function and response signal by exponential window function. Measurement frequency resolution was chosen to be $1 \mathrm{~Hz}$, and the number of averaging was 5 per DOFs.

At the beginning of modal test, FRFs were measured for the undamaged beam for 14 DOFs. These 14 measured FRFs were overlapped and showed 4 resonance peaks in the measurement frequency band, indicating four natural frequencies of the beam, figure 3 . 
Undamaged beam

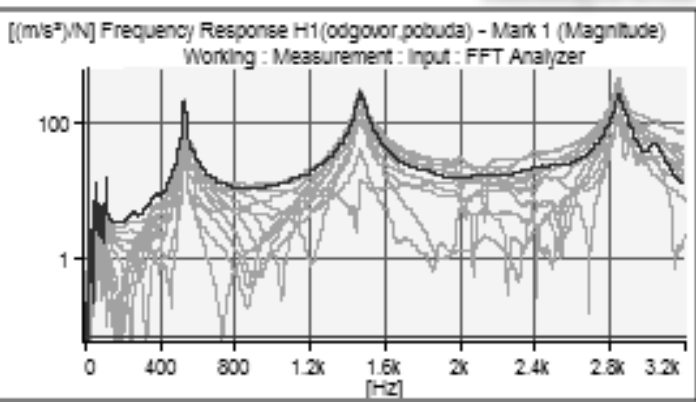

Figure 3. Overlapped FRFs for the undamaged beam

\subsection{Level 1 in damage detection: identification that damage exists in a structure}

After all modal tests were done (for 7 different depths of the cut), all FRFs measured at accelerometer location, that is DOF 11, were overlapped, figure 5. It is obvious from figure 5 , that there is some frequency shift due to increasing of the beam damage. Resonant peaks move to the left (decreasing frequencies) due to the beam stiffness decreasing (when level of damage increasing). Modal frequencies for 7 stages of damage are listed in table 2, and the relative change of natural frequencies (compared to undamaged beam natural frequencies) is listed in table 3 .

TEST 1

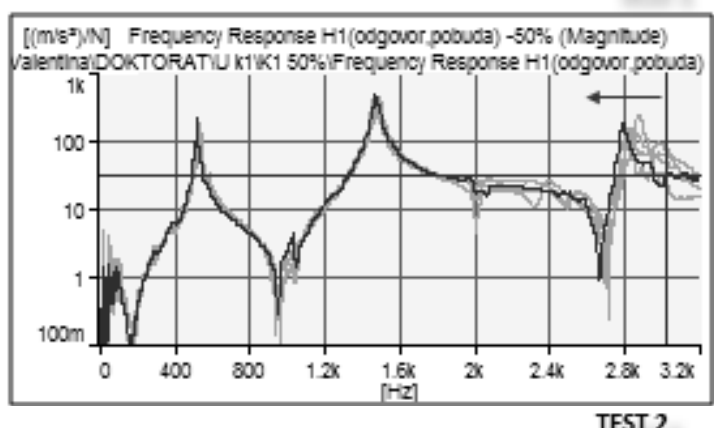

TEST 2

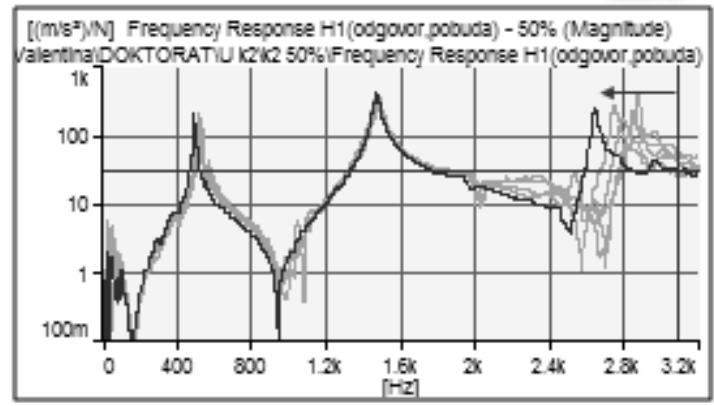

TEST 3

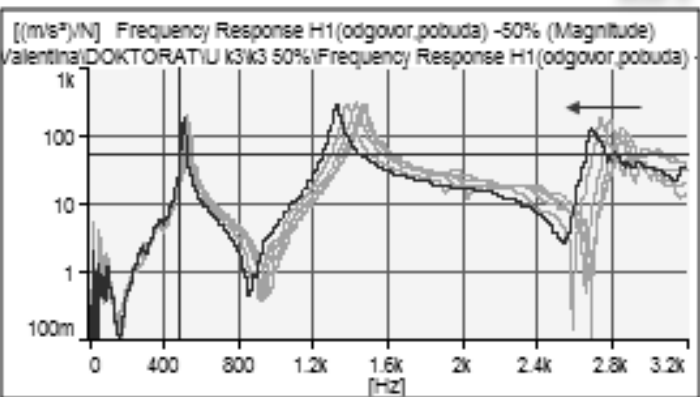

Figure 5. Overlapped FRFs for DOF 11, measured in test 1 , test 2 and test 3
Table 2. Natural frequencies for all damage stages

\begin{tabular}{|c|c|c|c|c|c|c|c|c|}
\hline \multicolumn{9}{|c|}{ Natural frequencies of cantilever beam $(\mathrm{Hz})$} \\
\hline \multicolumn{2}{|c|}{$\begin{array}{l}\text { Damage } \\
\text { stage }\end{array}$} & $\mathrm{d}_{0}$ & $\mathrm{~d}_{0}$ & $d_{1}$ & $\mathrm{~d}_{2}$ & $d_{3}$ & $\mathrm{~d}_{4}$ & $d_{5}$ \\
\hline \multirow{4}{*}{$\underset{E}{-}$} & f1 & 89 & 89 & 83 & 81 & 79 & 78 & 78 \\
\hline & $\mathrm{f} 2$ & 529 & 529 & 516 & 524 & 519 & 514 & 514 \\
\hline & f3 & 1482 & 1482 & 1463 & 1472 & 1463 & 1460 & 1467 \\
\hline & $\mathrm{f} 4$ & 2872 & 2872 & 2842 & 2849 & 2824 & 2810 & 2791 \\
\hline \multirow{4}{*}{$\underset{v}{N}$} & f1 & 87 & 87 & 83 & 81 & 79 & 79 & 78 \\
\hline & f2 & 520 & 520 & 518 & 519 & 509 & 501 & 485 \\
\hline & f3 & 1463 & 1463 & 1482 & 1473 & 1471 & 1473 & 1468 \\
\hline & $\mathrm{f} 4$ & 2849 & 2849 & 2873 & 2843 & 2783 & 2743 & 2644 \\
\hline \multirow{4}{*}{$\underset{n}{n}$} & f1 & 88 & 88 & 83 & 81 & 81 & 81 & 80 \\
\hline & $\mathrm{f} 2$ & 527 & 527 & 519 & 523 & 518 & 509 & 500 \\
\hline & f3 & 1465 & 1465 & 1469 & 1454 & 1422 & 1375 & 1322 \\
\hline & $\mathrm{f} 4$ & 2849 & 2849 & 2868 & 2831 & 2784 & 2736 & 2684 \\
\hline
\end{tabular}

Table 3. Relative change of natural frequencies

\begin{tabular}{|c|c|c|c|c|c|c|c|c|}
\hline \multicolumn{9}{|c|}{ Relativ change of natural frequencies } \\
\hline \multicolumn{2}{|c|}{$\begin{array}{l}\text { Damage } \\
\text { stage }\end{array}$} & $\mathrm{d}_{0}$ & $\mathrm{~d}_{0}$ & $\mathrm{~d}_{1}$ & $\mathrm{~d}_{2}$ & $\mathrm{~d}_{3}$ & $\mathrm{~d}_{4}$ & $\mathrm{~d}_{5}$ \\
\hline \multirow{4}{*}{ 馬 } & f1 & 1 & 1 & 0.932 & 0.91 & 0.88 & 0.87 & 0.87 \\
\hline & f2 & 1 & 1 & 0.975 & 0.99 & 0.981 & 0.971 & 0.971 \\
\hline & f3 & 1 & 1 & 0.987 & 0.993 & 0.987 & 0.985 & 0.989 \\
\hline & f4 & 1 & 1 & 0.989 & 0.991 & 0.983 & 0.978 & 0.971 \\
\hline \multirow{4}{*}{ 先 } & f1 & 1 & 1 & 0.954 & 0.931 & 0.91 & 0.91 & 0.89 \\
\hline & $\mathrm{f} 2$ & 1 & 1 & 0.996 & 0.998 & 0.978 & 0.963 & 0.932 \\
\hline & f3 & 1 & 1 & 1.01 & 1.006 & 1.005 & 1.006 & 1.003 \\
\hline & $\mathrm{f} 4$ & 1 & 1 & 1.008 & 0.997 & 0.976 & 0.962 & 0.928 \\
\hline \multirow{4}{*}{ 奋 } & f1 & 1 & 1 & 0.943 & 0.92 & 0.92 & 0.92 & 0.909 \\
\hline & f2 & 1 & 1 & 0.985 & 0.992 & 0.983 & 0.966 & 0.949 \\
\hline & f3 & 1 & 1 & 1.002 & 0.992 & 0.97 & 0.938 & 0.902 \\
\hline & $\mathrm{f} 4$ & 1 & 1 & 1.006 & 0.993 & 0.977 & 0.96 & 0.942 \\
\hline
\end{tabular}

\subsection{Level 2 in damage detection: damage location}

For the purpose to locate the damage, good result was achieved using the general damage index - GDI, [9]:

$$
G D I_{d}(p)=\frac{\sum_{\omega} \beta_{d}(p, \omega)}{N_{\omega}}
$$

Index GDI has to be calculated for each DOF of the cantilever (marked with $p$ in this equation) and for each stage of damage (marked by $d$ ). The number of natural frequencies in the band of interest is marked by $N_{\omega}$. The coefficient $\beta_{d}(p, \omega)$ is calculated from:

$$
\begin{aligned}
\beta_{d}(p, \omega) & =\frac{\left({ }^{d} \alpha_{i}^{\prime \prime}(\omega)^{d} \overline{\alpha_{i}^{\prime \prime}(\omega)}+\sum_{i=1}^{N} d \alpha_{i}^{\prime \prime}(\omega)^{d} \overline{\alpha_{i}^{\prime \prime}(\omega)}\right)}{\left(\alpha_{i}^{\prime \prime}(\omega) \overline{\alpha_{i}^{\prime \prime}(\omega)}+\sum_{i=1}^{N} \alpha_{i}^{\prime \prime}(\omega) \overline{\alpha_{i}^{\prime \prime}(\omega)}\right)} . \\
& \cdot \frac{\sum_{i=1}^{N} \alpha_{i}^{\prime \prime}(\omega) \overline{\alpha_{i}^{\prime \prime}(\omega)}}{\sum_{i=1}^{N}{ }^{d} \alpha_{i}^{\prime \prime}(\omega)^{\bar{d} \alpha_{i}^{\prime \prime}(\omega)}}
\end{aligned}
$$


where curvature of FRF is marked by $\alpha_{i}^{\prime \prime}(\omega)$ for the undamaged beam, and by ${ }^{d} \alpha_{i}^{\prime \prime}(\omega)$ for the damaged beam, at $d$ stage of damage. The symbol represents the conjugate operator and $N$ is the total number of DOFs (or measuring points).

The curvature of FRF is calculated from central differences:

$$
\alpha_{i}^{\prime \prime}(\omega)=\alpha_{i-1}(\omega)-2 \alpha_{i}(\omega)+\alpha_{i+1}(\omega)
$$

where $i=p=(2, \ldots, N-1)$.

However, GDI index defined from equation (6) was still not enough sensitive for the low level of damage. Some measurement inaccuracies occurred on the certain DOFs during testing could be averaged, but it is supposed that GDI should increase continuously on the location on damage. Thus, the new index, named cumulative $G D I$ was proposed, [7]. The cumulative GDI was calculated by successive adding the values of $G D I$ for the each level of damage:

$$
G D I_{\text {cum_d }_{d}}=G D I_{d}+G D I_{d-1}
$$

Figure 6 shows cumulative GDI indicating the location of damage between measurement DOFs for the last stage of damage $\mathrm{d} 5$ for all three tests.

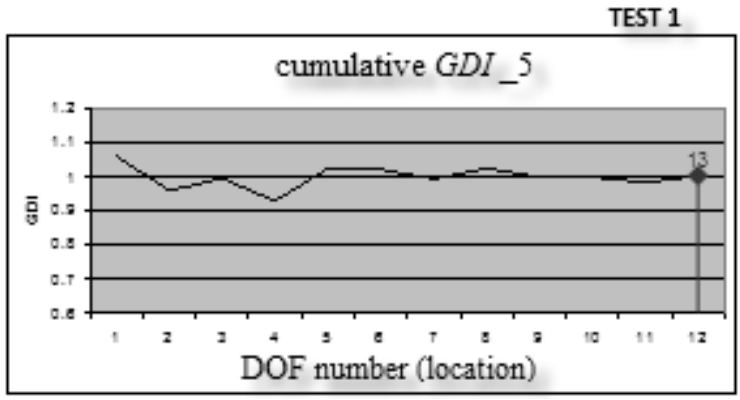

TEST 2

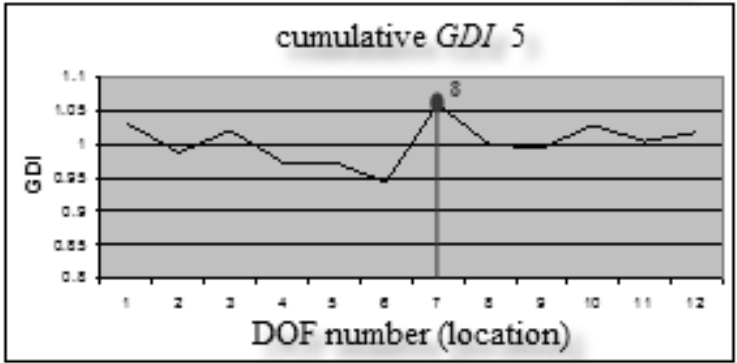

TEST 3

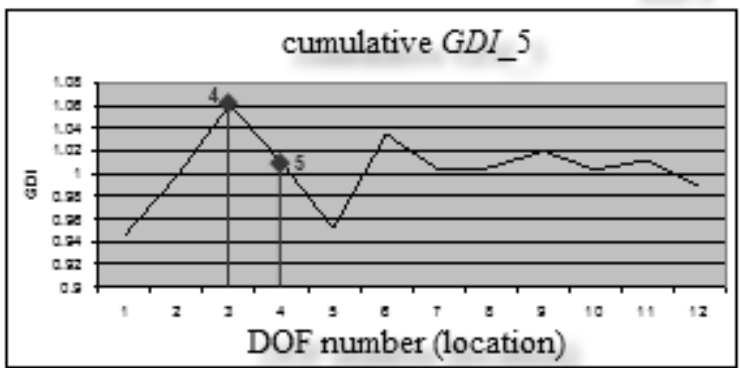

Figure 6. Indication of the damage location

From figure 6 , it is obvious for the test 1 that there is a problem with identification of damage if damage is located near the place where beam is clamped. If the damage is located at some nodal point of the structure, like is in the test 2 , there is no problem that GDI identify a location of damage. Good identification is achieved in test 3 , where a damage is located far away from the place of clamping.

\subsection{Level 3 in damage detection: damage quantification}

The damage detection philosophy is based on correlation between to state of the structure: one is state before the damage appearance, e.g. healthy structure; the other is some damaged state of the structure. These to states can be described by vector (one column from FRF).

To measure the degree of correlation between two vectors, W. Heylen [8] defined a response vector assurance criterion (RVAC), figure 7, with only one applied force, so that the receptance FRF matrix turns to be just a vector:

$$
R V A C_{-} d(\omega)=\frac{\left|\sum_{j=1}^{N}{ }^{d} \alpha_{j}(\omega) \overline{\alpha_{j}(\omega)}\right|^{2}}{\sum_{j=1}^{N}\left[{ }^{d} \alpha_{j}(\omega)^{\bar{d} \alpha_{j}(\omega)}\right] \sum_{j=1}^{N}\left[\alpha_{j}(\omega) \overline{\alpha_{j}(\omega)}\right]}
$$

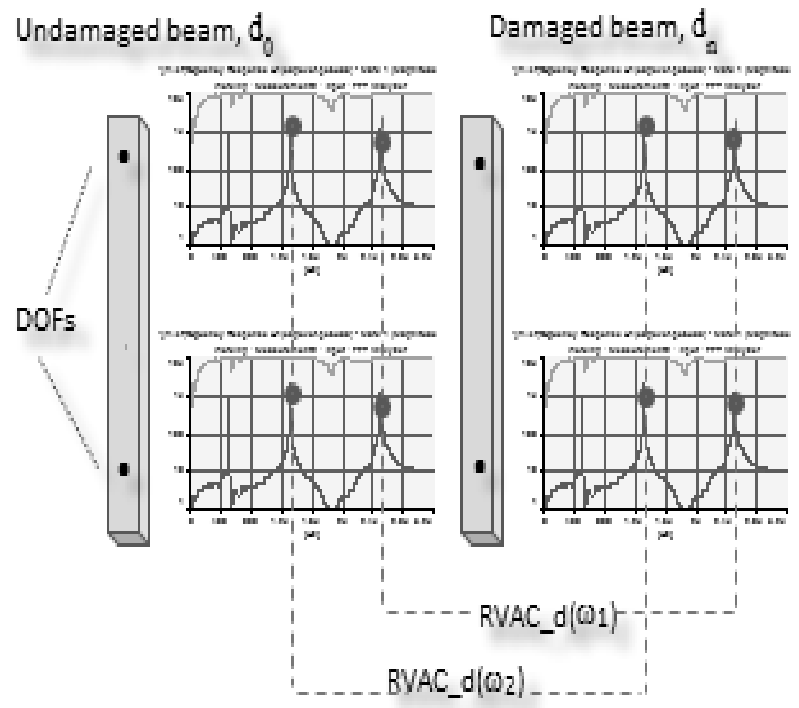

Figure 7. Graphical interpretation of the RVAC

Sampaio and Maia [9] present some new development of the Detection and Relative Damage Quantification Indicator, formulated as:

$$
D R Q_{d}=\frac{\sum_{\omega} R V A C_{d}(\omega)}{N_{\omega}}
$$

where $N_{\omega}$ is the number of frequencies and, so, DRQ will vary between 0 and 1 .

After calculation the Detection and Relative damage Quantification indicator, results are graphically interpreted as follow on Figure 8. It is obvious that DRQ indicator shows decreasing trend with increasing the level of damage. Therefore, the DRQ indicator is able to detect and relatively quantify damage. 
TEST 1

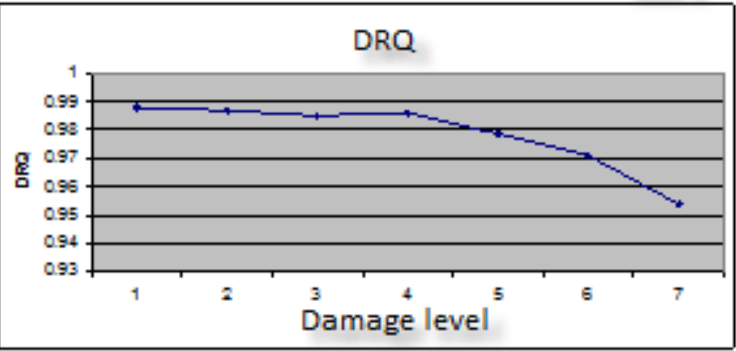

TEST 2

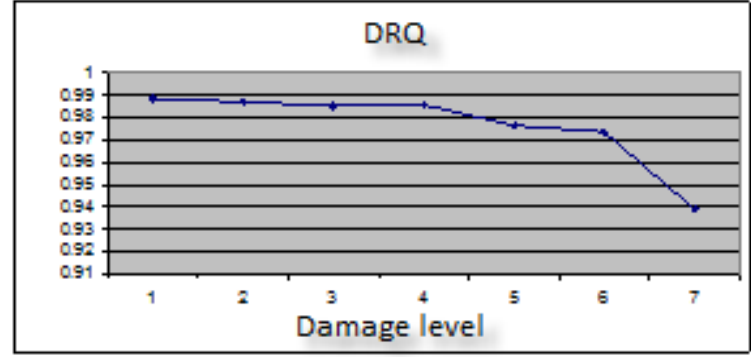

TEST 3

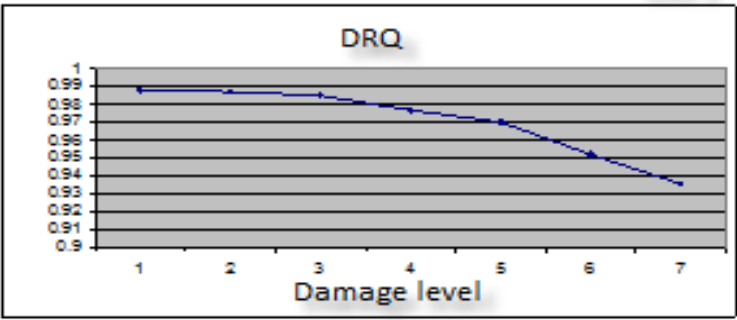

Figure 8. Relative quantification of damage by the DRQ

\section{CONCLUSION}

This paper presents one approach in damage detection using FRF data. It is point out that measured FRF data used for damage detection has many advantages over the traditional methods using modal analysis data, especially that FRF data provide abundant information on the dynamic behavior of a structure. The results of experiments show that frequency shift in FRFs directily shows that damage exist in the structure. The DRQ indicator is able to detect and relatively quantify the damage, that is to recognize the pattern of damage variation. To localize the damage on the structure, it is supposed that GDI indicator should increase continuously on the location on damage, thus some improvement of the GDI indicator is proposed, that is the cumulative GDI. Described damage detection method showed good performance even for the hammer excitation and just one response transducer used.

\section{REFERENCES}

[1] Rytter A.: Vibration based inspection of civil engineering structures, Ph.D.Dissertation, Department of Building Technology and Structural Engineering, AalborgUniversity, Denamrk, 1993.

[2] Doebling S.W., Farrar C.R., Prime M.B., Shevitz DW., Damage Identification and Health Monitoring of Structural and Mechanical Systems from Changes in their Vibration Characteristics: A Literature Review, Los Alamos National Laboratory report LA-13070-MS.,1996.
[3] Farrar C.R., Doebling S.W.: Vibration-Based Damage Detection, Los Alamos National Laboratory Report, 1999.

[4] Sohn H., Farrar C.R.: A Review of Structural Health Monitoring Literature: 1996-2001, Los Alamos National Laboratory report LA-13976-MS, 2004.

[5] Yan Y.J., Cheng L., Wu Y.Y., Yam L.H.: Development in vibration-based structural damage detection technique, Mechanical System and Signal Processing 21, 2198-2211, 2007.

[6] He J.: Damage Detection and Evaluation I, Modal Analysis and Testing, NATO Science Series, 1999.

[7] Golubović-Bugarski V.: Models of correlation between structural damages and dynamics response of mechanical structure (Modeli korelacije strukturnih oštećenja sa dinamičkim odgovorom mehaničkog sistema), Ph.D.thesis, University of Banja Luka, Banja Luka, 2010.

[8] Heylen W.: Modal analysis theory and testing, Katholieke Universiteit Leuven, 1997.

[9] Sampaio R.P.C., Maia N.M.M.: Strategies for an efficient indicator of structural damage, Mechanical System and Signal Processing, Vol.22, 2008.

\section{ЈЕДАН ПРИСТУП У КОРЕЛАЦИЈИ СТРУКТУРНИХ ОШТЕЪЕЊА СА ДИНАМИЧКИМ ОДЗИВОМ КОНЗОЛНЕ ГРЕДЕ}

\section{Валентина Голубовић-Бугарски}

У раду су представљен један приступ у детекцији структурних оштећења базиран на коришћењу измјерених функција фреквецнијског одзива, ФРФ. Указано је да коришћење ФРФ у детекцији структурних оштећења има низ предности у односу на традиционалне методе у којим се користе модални подаци добијени модалном идентификацијом. Наиме, ФРФ у себи садрже све информације о динамичком понашању система, тако да се не губи на њиховој тачности усљед нумеричке манипулација, што је неизбјежно у модалној идентификацији. Спроведено је експериментално истраживање на конзолној греди. Резултати показују да помјерање резонантних врхова у ФРФ директно указује на постојење структурног оштећења. Индикатор детекције и релативне квантификације оштећења, ДРQ, успјешно указује на постојање и промјену ниво оштећења, тј. указује на тренд пропагације оштећења. Локализација оштећења на структури успјешно је извршена коришћењем кумулативног индикатора ГДИ. Презентовани метод детекције оштећења показује добро функционисање и при коришћењу модалног чекића као метода побуђивања структуре, те једног акцелерометра за аквизицију одзива, што је од велике важности за скромније опремљене лабораторије, као и употребу на терену. 